\title{
PAUL'S USE OF THE TERM "MAN".
}

BY RfV. O. P. GaChHS, D. D., Hightstown, N. J.

Paul is a severely logical writer as is evident in the structure of the letters to the Romans and the Galatians. He is skilled in the use of figures of speech, in themselves condensed arguments. In his writings we find a frequent use of the term "man", a figurative expression condensing into one word an entire volume of theology.

1. The terms "inward man" and "outvard man" are contrasted in Rom. $7: 22$ and 2 Cor. $4: 16$. The outward man is the physical organization which the saint and the ungodly alike possess. If one live to the one hundred and twenty years of Moses with the natural powers unabated and the eye undimmed yet, in time, the physical nature withers away. The closing chapter of Ecclesiastes describes in a forcible way the declining old age when the physical life oftentimes becomes a burden. Under the stress of the affictions endured in 2 Cor. $11: 24-27$-stripes, imprisonments. hungers-the outer manhood of Paul would naturally give way. He is moved to make this statement concerning the breaking down of the physical system by reason of the future glory awaiting him, the indestructible and glorious body soon to be his, spoken of in the next chapter. He became in time "Paul the aged" (Philemon) and shivers in the Mammertine prison awaiting the arrival of the cloak (2 Tim. 4:20). In contrast with the "outward man" that is oftentimes a source of moral danger ( 1 Cor. $9: 27)$ is the "inward man." To sare the body from peril, handcuffs, imprisonment, fire, death, Peter turned his back on Christ and Canmer recanted the Protestant faith. Is the "inward man" something common to all men, the indestructible, immortal life, or is it something peculiar to the redeemed man. A divergence of view arises here. That all alike, the bad and the good. have an unending existence is distinctly taught by Jesus (Matt. $25: 46)$. Something akin to Paul's expression "the inner man" is found in prior heathen writings, "a man within a man". It 
may be assumed that Paul does not mean that there is an inner miritual body that has an existence within the external organization, as taught by Tertullian and Menken. Alford and Dean Stanley hold that. Paul means here simply the soul as Jistinct from the body. Dr. Hodge says the inner man is the man's higher nature as subject to the divine life. Meyer, in general, holds that the inner man is that part of our nature that is open to the divine grace, whereas the "new man" is the product of the divine Spirit. These writers regard the inner man as a common possession of all men, an inner spiritual element of human nature. In some cases this inner part is made bitter by affictions, as in the case of Pharaoh; in Paul's life the inner nature was so purified and strengthened by divine grace that he rejoiced in infirmities (2 Cor. 12:9). By comparison of these passages (Rom. $7: 22 ; 2$ Cor. 4:16) with Rom. $7: 23$ it will be seen that the expression, inner man, is applied to the redeemed alone; all men alike have an immortal nature, but only the saint has an inner man, in its true sense. Jude speaks of the regenerate alone as having the Spirit (ver. 19). With the inner man the law of God is loved; here evidently the inner man does not embrace the entire inner life of Paul. Part of that life is called "the mind," part is called "the flesh" (Rom. $7: 25$ ); a holy tendency and an unholy tendency existing side by side in the same life, at the same time. With the mind he serves the law of God, with the flesh the law of sin. By "flesh" he has no reference to the outward physical organization, as though that were the source of sin, as many erroneously held, but a certain downward tendency, a depravity within him. Peter uses a like expression, "the hidden man of the heart" (1 Pet. 3:4), almost equivalent to Paul's inner man. It may be affirmed that the Pauline expression "inner man" is not synonymous with soul, but alludes to the regenerate man, applicable to the nature that loves God, that serves Christ, that is antagonistic, in its very essence, to unholiness. Meyer says on the growing strength of the inner man, "this is here a noble testimony to the consciousnes that the constant development of the spiritual life is not dependent on the condition of the body." There is a mutual dependence 
of the physical and immaterial nature upon each other, a certain physical basis of life so that a disordered brain will affect the mind. A broken-down nervous system may make a dispirited Elijah or John the Baptist, may give occasion for Peter to lie, may cause the believer, for a time, to recant (Acts 26:11). But it remains true that the approaching glory of the impending life and the constantly enlarging and supported inner man should hallow and inspirit the decaying physical life. Physical infirmity and a joyous and happy old age or a shut-in life may be joined together.

The expression "day by day" (2 Cor. $4: 16$ ) shows that the spiritual life is not perfected at once, but that its renewal is a gradual, dafy process. In like manner salvation may be looked at as something complete, "saved" (Titus $3: 5$ ), or as a process, being saved (Acts $2: 47$ ). The passage in Rom. $7: 23$ reveals a conflict in the inner life. Many have a mistaken and mischievous idea that Paul describes conversion as the insertion of a new individual life, pure and sinless, into the man's nature, so that from this time there is an inner man that canrot sin and a fleshy life that cannot but sin. The seventh chapter of Romans describes, not two Pauls, but one Paul in an individual life, with an overcoming and growing tendency toward holiness, but with another tendency to relapse into sin. He sometimes lives in the upper scale of life, sometimes he falls below his ideal self and lives in the lower scale. It is one Paul all the time whose experiences we are reading. Paul's experience is repeated to-day in every life that has, to any large degree, his enthusiasm in the Christian life. Every high living Christian man will find in his own heart a Dr. Jekyl and a Mr. Hyde. Easy going lives do not and cannot know the meaning of Paul's intense terms; they are too high for them. Paul finds three laws: the law of God abiding and commanding; the law of sin, an indwelling tendency to sin, not ruling, but fighting; the law of the mind, the inner man, the prevailing tendency toward serving God. The growth of the inner man is shown in Paul's enlarging conception of sin. Before his conversion in the light of the letter of the law was blameless (Phil. 3:6); in A. D. 58, with over 
twenty years growth as a Christian, he views himself as "the least of the apostles" ( 1 Cor. 15:9) ; in A. D. 63 he styles himself less than the least of all saints (Eph. 3:8) ; in A. D. 65, nearest the end, he is the "chief of sinners" (1 Tim. 1:15).

2. The old man and the new man are contrasted in Rom. 6:6; Eph. $4: 22$; Col. $3: 9,10$.

In Rom. 6:6 Paul declares that the old man has been crucified. In Eph. $4: 22$ and Col. 3:5, he urges his readers to put off the old man, with all his works, because the new man has already been put on. The "old man" was put off at a certain definite time, it was a definite act. This is shown by the aorist tense employed (Eph. 4:22; Col. 3:9). Ellicott says, on the use of the aorist tense, "the aorist is used with reference to the speedy, single nature of the act. The "old man" refers partly to the former legal condition, as condemned under sin, partly to the moral character of the person. In what way was the old man put off, crucified? If we look at this description alone we would be obliged to conclude that every Christian man must be a sinless man. The old man is crucified, dead, buried. In Rom. 6:4 the first century Christian made confession through his baptism that he was dead, buried as utterly dead, and risen to a new life. How can such a man sin at a!l? This is one side of Paul's teaching. It is the picture of what is contained in the new life when finished, it is the ideal, the conception of the Christian life, what the Christian desires to be, aims to be. It is the prophecy and outline of the Christian life as it is in Christ's mind from the first, to be deflnitely realized in the Christian life when the work is finished. The other side of Paul's teaching is found in Rom. 8:13-" "put to death." Paul says, "Because you are ideally dead, therefore in your life be practically dead; because you are dead in symbol, kill all your sinful life that the ideal and the actual may coincide." There are the same ideal and seemingly contradictory statements in John's writings. "If we say that we have no sin we deceive ourselves" ( 1 John $1: 8$ ); "he cannot in because he is begotten of God" ( 1 John 3:9). There was the beginning of a sinless life, sinlessness is involved potentially in the newly begotten spiritual life. Both sides 
of John's teachings must be taken together to get the complete truth; either taken alone and pressed to its limit will lead to vast error. In like manner both sides of Paul's teaching must be looked at that the entire truth may be seen. It is oftentimes true that a half truth unduly pressed will be practically an entire falsehood. In Eph. $4: 24$, and Col. $3: 10$, the "new man" is represented as assumed once for all as indicated by the aorist tense; at the same time the old man is to be gradually and steadily put off. Meyer says: "Observe the change of tenses. The laying aside of the old man is represented as a momentary act (aorist); the being renewed is an enduring process (present) ; the final act of which is putting on of the new man (present)". See his commentary on Eph. 4:22,23. In Col. 3:9 Paul uses a very strong expression (ap-ek-dusamenos), having utterly put off the old man. The Christian has come out of the state of condemnation into that of sonship; the old man is dead; he is now living a new life under the guidance of the Holy Spirit; he is getting each day a better control of himself, is growing in the knowledge of God; he is displacing the old life with the new.

Tennyson sings :

\section{"Ah for a man to arise in me, That the man I am may cease to be."}

This is Pauline theology in modern verse. To the Colossians Paul writes: "You have put off once for all the old man (3:9); you have once for all put on the new man $(3: 10)$; therefore in detail put away everything that belongs to the old man $(3: 5)$; because you are ideally and potentially new men, in your daily life be new men; let the ideal and the practical be commensurate in your lives."

A distinct school of theological writers, especially among the Plymouth Brethren, speaks of two distinct men occupying the same life; an old man condemned, sinful; a new man, begotten of God, that cannot sin. One writer of this school says: "When a man of God goes into sin there is a part of him which does not fall for he has been begotten of God." This is utterly un-Pauline in its affirmation. Some Anti- 
nomian writers so far misconstrue Panl's words, "It is no more I that sin but sin that dwelleth in me", as to make a Christian man guiltless in doing even the greatest wrongs, throwing off the responsibility from Paul to an imaginary other man, an "old man" dwelling in him. Paul did not disclaim responsibility even while he deplored a remaining indwelling tendency toward sin. In Gal. 3:2 Paul speaks of the Christian having put on Christ, an act done once for all, the act of justification. In Rom. 12:14 he exhorts the Roman Christians to put on Christ, the daily process of making the life conformed to Christ's will. One side of Paul's teaching is the complete conception, the pattern of the Christian life as it is in its nature, high, ideal, holy; the other side is the recognition of our imperfectly holy life, urging it to be conformed to the pattern.

3. The "new man" is contrasted with old race hatreds in Eph. 2:15.

Jesus Christ has made in himself one new man. He has reconciled men to God by his death on the cross. He has reconciled men to each other, creating a new sense of brotherhood. Kneeling before the same cross and sitting at the same holy Supper, redeemed by the same blood, animated by the same hope, living for the same person, they become one new people. There had been a deep gulf between the Jew and the Gentile; ihere were great racial hatreds that alienated men. Jesus makes a new brotherhood among men. "Barbarian, Scythian, bond, free" recognize each other as kinsmen. There is a moral significance in the term "new" as maintained by Ellicott against Meyer. The founder of the Hague tribunal is Jesus Christ. Social and class distinctions will be displaced only as Jesus infuses his spirit in men. Jesus is the peacemaker between men and God, between man and man. The passages in Acts 15 and Galatians 2 show how nearly the early Christian church, humanly speaking, was cleft into two parts by the mutual antagonism-Jew and Gentile. One of the great hindrances to church growth in India is the presence of caste with its hatreds and contempts. When Christ gets control there is the expulsive power of a new affection. 
4. The "new creation" and old things, are contrasted in 2 Cor. $5: 17$.

The "new creation" is synonymous with the "new man" wronght by the Holy Spirit. The "old things" correspond with the "old man" that has passed away. In outline, in God's plan and purpose, in the saint's desire and effort, there is a distinct new creation. New views of things have come, new aims and impulses are in the life, new hopes are born, a new life has come. Those to whom Paul writes are designated as saints (1 Cor. 1:2). But the entire letter shows how imperfect was their saintship, how much there was needed in their moral life to make it correspond with the description given of them in 1:2. The letter discloses party spirit, selfishness, unbrotherliness, a desire for a showy life, low conceptions of church purity. By their profession and in their baptism ( 1 Cor. $6: 11$ ) they had symbolically put away all the old life; they must now, by reason of this, lift their life up to correspond with their confession. They must not, to use the words of Epictetus, have a creed of gold and a conduct of earthenware. When David Mendel in Germany became a Christian he assumed a new name, David Neander, which was in reality David New Man.

5. The "old leaven" and "new lump" are contrasted in 1 Cor. $5: 7$.

We have here, under differing figures, the old man and the new man again brought before us. At the Passover the house was searched that every particle of leaven might be removed. Because the Corinthians are Christians they are regarded as unleavened, there is nothing of the old leaven in their hearts. This is the ideal side of their life. Actually there are many things in their personal and church life that exhibit the old leaven, the presence of sin. They had a proud and divisive spirit; they were living very far below the highest possible life. The old leaven very largely influenced their lives. Paul urges them, because in theory they are unleavened, to remove all the leaven yet found in them that they may be a new lump. "You are holy ideally, therefore be holy in the domain of your practical life-lift your life up to the pattern that 
Christ makes for it. Let conduct and confession coincide in your life"-in this way Paul writes to them.

6. A "new creation" and religious ceremonial are contrasted in Gal. $6: 15$.

The Galatian Christians were in danger of being swept away from the simplicity of the Gospel by a false teaching-the need of a ritual salvation. Paul's emphatic word was faith, to the exclusion of all works as a basis for salvation. His formula was Christ alone as Savior, not Christ plus circumcision. This leads Paul to say that outward ritual or its absence amounts to nothing; it is a matter of utmost indifference; the only important thing is that a man should be a converted man, transformed into a new spiritual condition. He does not deny the place of a rite in the Christian life, for he bears witness to the universal prevalence of a burial in baptism (Rom. 6:14). But there is a great gulf between a rite imposed by Christ upon believers, for teaching, confessing and witnessing purposes, and ritualism which makes the spiritual life depend upon an outward and physical thing. Believers' baptism and baptismal regeneration are at the opposite extremes of thinking. Nothing avails to change a man's spiritual condition, neither circumcision nor baptism, nothing but a change of heart. The Galation teachers put circumcision first, Christ second. Paul says, put Christ, the Holy Spirit, conversion, faith, the Christian life first. If we magnify Christ, rites and the church and church ordinances will be of great use. If they usurp the first place, they will be changed from blessings into curses. All Pedo-baptist organizations today place baptism and church first, in order of time; the Baptist churches, following Paul's letter to the Galations, affirm that no person has anything to do with baptism, church or cupper until first of all he has met Christ in person.

A right conception of Paul's new man, new creation, new lump, will help believers to put away the old man, the old Inmp, the old things. A right philosophy and a right interpretation are a help to right living. In time Christianity, as it now makes a new man and a new creation, will make a new wong, a new name, a new heaven and a new earth. 